Int. J. Curr. Res. Med. Sci. (2017). 3(5): 46-60

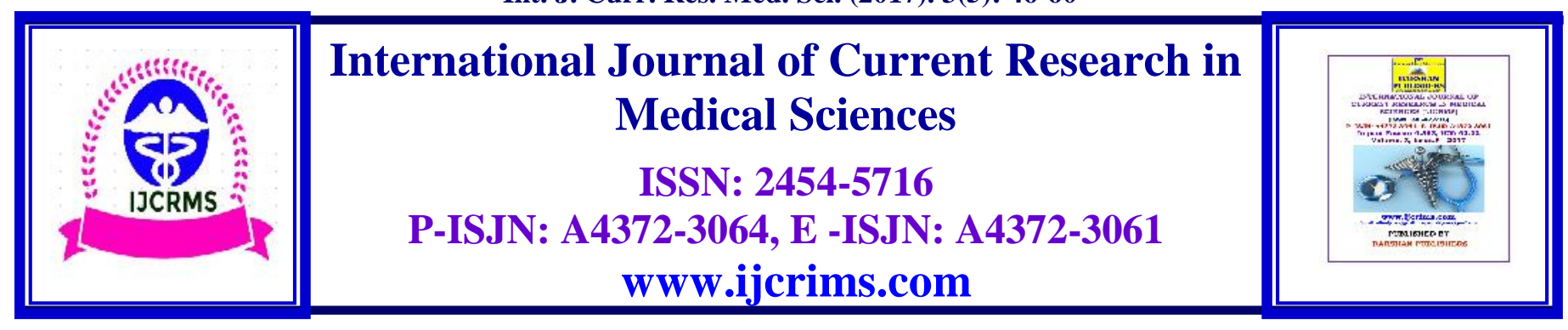

DOI: http://dx.doi.org/10.22192/ijcrms.2017.03.05.009

\title{
Speckle tracking versus tissue Doppler assessment of Right ventricular function in inferior wall myocardial infarction and angiographic correlation to proximal right coronary artery stenosis
}

\author{
Mohamed Mahmoud*, Mohamed Salah A. Elsalam**, Hatem A. elrahman*** \\ and Tarek A.M. Khalifa**** \\ *Al-Azhar University Faculty of Medicine Cardiology Department*, \\ * Assiut, Assiut University Faculty of Medicine Cardiology Department \\ ***Assiut, Sohag General Hospital Cardiology Department \\ $* * * *$ Sohag, Egypt \\ *Corresponding Author
}

\begin{abstract}
Right ventricular (RV) function, has not been widely studied after acute myocardial infarction (MI). The current study describes the use of recent modalities of echocardiography (Echo) to provide a simple accurate diagnosis of ventricular functions post acute inferior MI.

Aims of the study: The assessment of the RV functions in acute inferior wall MI using ventricular strain assessed by $2 D$ longitudinal speckle tracking in comparison to tissue Doppler imaging (TDI) as well as correlation of the results of $R V$ function with the angiographic data of right coronary artery $(R C A)$ stenosis in the first episode of acute inferior wall MI.

Patients \& methods. In The patient group composed of 45 patients with first episode of acute inferior MI, twenty patients were selected for the control group. All 65 patients underwent echo assessment indices of dimensions, ventricular function (EF, FS and TAPSE), ventricular myocardial velocities by TDI and global longitudinal strain of both ventricle by speckle tracking. Patients were then divided into two groups A and B according to the presence or absence of significant proximal RCA stenosis.

Results: The study included 45 patients with first episode of IWMI underwent coronary angiography (group2) and 20 persons as control (group1). TAPSE, TDI derived systolic and early diastolic velocities as well as global longitudinal strain assessed by $2 D$ - speckle tracking all were significantly reduced in patients versus control group. On the other hand, patients with proximal RCA stenosis (group A, 17 patients) compared to non-proximal RCA lesions (group B,28 patients) had significantly lower EF, FS, TAPSE, impaired both systolic and diastolic function of RV including TDI derived velocities and global longitudinal strain which assessed by $2 D$ - speckle tracking.

Conclusion: $R V$ functions may be globally significantly reduced in those with first attack of inferior wall MI particularly those with proximal RCA lesions detected by recent modalities of echo even in those with apparently normal traditional echo parameters.
\end{abstract}

Keywords: inferior myocardial infarction, $R V$ function, echocardiography, TDI Tissue Doppler imaging, speckle tracking, and Two-dimensional strain. 


\section{Introduction}

In recent years, $\mathrm{RV}$ infarction seems to be under diagnosed in most cases of acute myocardial ischemia despite its frequent association with inferior-wall and, occasionally, anterior wall MI. However, its initial management is drastically different from that of left ventricular (LV) MI, and studies have indicated that RV infarction remains associated with significant morbidity and mortality (Inohara et al ., 2013)(1).

Furthermore, echo evaluation of RV function has been more challenging than that of LV mainly because of the complex structure and asymmetrical shape of the RV. The recent introduction of speckle-tracking echo provides objective measures to quantify segmental and global ventricular function independently of angle of incidence, chamber translation, cardiac rotation, and ventricular size (Takamura et al , 2010)(2).

The recent advances in non-invasive modalities, provide a more accurate diagnosis of $\mathrm{RV}$ infarction (Inohara et al ., 2013) (3).

Strain and strain rate (SR) are measures of deformation that are basic descriptors of both the nature and the function of cardiac tissue. These properties may now be measured using either Doppler or two-dimensional ultrasound techniques. Although these measurements are feasible in routine clinical echo, their acquisition and analysis nonetheless presents a number of technical challenges and complexities (Marwick et al., 2006) (4).

\section{Patients and Methods}

Patient selection: All selected patients were admitted to the coronary care unit, department of cardiology, faculty of medicine, Assiut University from March 2015 to January 2016 with first episode of acute inferior MI recruited for this study and sixty (60) patients from them were selected.
Control group: Twenty age and sex matched persons who were apparently healthy subjects were enrolled in the study as the control group. The following was done for All patients, 1. Informed consent, 2. Full history taking, 3. Complete general and local examination, 4. Total lab investigations 5. Full echocardiographic study including conventional echo (M-mode, Doppler, 2D) \& tissue Doppler image and speckle tracking for assessment of aVentricular dimensions (left atrial (LA) diameter, aortic root diameter, LVEDD, LVESD).

b- Ventricular functions: EF, FS, Tricuspid annular peak systolic excursion (TAPSE), TDI assessment of peak systolic velocity of both ventricles $(\mathrm{Sm})$, diastolic atrial peak velocity $(\mathrm{Am})$, early diastolic peak velocity (Em), E/A ratio and global longitudinal strain of both ventricles. 6.Coronary angiography within one month from the first episode of acute inferior MI in cardiac catheterization unit using device of Siemens Biplane Axiom Artes Zee VC14 with the following views, A-P, RAO, A-P caudal, LAO caudal and cranial views for the left system, RAO and LAO for the right coronary artery and they were classified into group A and group B based on the presence or absence, respectively, of a significant proximal RCA stenosis.

-Statistical analysis: Data was analyzed using STATA intercooled version 12.1. Quantitative data was represented as mean, standard deviation, median and range. Data was analyzed using student t-test to compare means of two groups. When the data was not normally distributed Mann-Whitney test was used. Qualitative data was presented as number and percentage and compared using either Chi square test or fisher exact test. ROC curves were constructed to obtain optimal cut off value of different parameters to predict predict proximal RCA stenosis. Data were analyzed by sensitivity, specificity, positive, and negative predictive value derived from the receiver operating characteristic (ROC) curve. Graphs were produced by using Excel or STATA program. $\mathrm{P}$ value was considered significant if it was less than 0.05 . 


\section{Results}

A total of 65 persons, 45 in the patient group and 20 in the control group, were enrolled in the study.

* Group 1(patients group) had 45 patients suffering of acute inferior MI, with a mean age of $55.42 \pm 9.77$ years. There were 37 males $(82.22 \%)$ and 8 females $(17.78 \%)$.

Group 2 (control group) had 20 populations, with a mean age of $51.5 \pm 7.86$ years. There were 12 males (60\%) and 8 females (40\%) were enrolled in the study.

a) Two groups matching together according to age and gender in the following table (1).

\section{b) General Echo findings:-}

1- Echo dimensions: LV dimensions (LVEDD \&LVESD) are significantly larger in the patients group compared to control group, Mean \pm $\mathrm{SD}$ of the LVEDD is $54.46 \pm 6.16$ in patient group compared to Mean \pm SD of the LVEDD is $49.6 \pm 1.95$ in control group, Mean \pm SD of the LVESD is $37.13 \pm 6.53$ in patient group compared to Mean \pm SD of the LVESD is $27.65 \pm 2.72$ in control group.

In the other hand there is no significant difference in other dimensions (Lt. atrial \& aortic root diameters) between two groups as shown in the table (2)

2- Echo findings according to ventricular function: i. LV function (EF\&FS) was significantly lower in patients group than control one as the following: $\mathrm{EF} \%$ were (Mean \pm SD 58.02 \pm 8.47 ) in ii. Patients group compared to (Mean \pm SD 64.65 \pm 4.97$)$ in control group, FS in group (1) were (Mean \pm SD 31.2 \pm 5.98 ) compared to (Mean \pm SD 35.7 \pm 3.97$)$ in group (2).

iii. RV function: RV systolic function which assessed by TAPSE was better in control group than patients group that were (Mean \pm SD 22.4 \pm 2.6 ) in group (1) compared to (Mean \pm SD24.1 \pm 2.6 ) in group (2), All these findings are shown in table (3).

\section{c) TDI by echo:}

Both systolic and diastolic functions of the RV were significantly lower in patients group compared to control group regarding peak early diastolic velocity $(\mathrm{Em})$, E/A ratio and peak systolic velocities $(\mathrm{Sm})$ of the free wall of the RV. On the contrary, there were no significant differences between two groups as regard peak atrial diastolic velocity (Am) of the free wall of the RV.

All of these data shown in the table (4) .

d) speckle tracking by 2D- echo: The RV systolic function was significantly better in control group(2) than patients group according to global longitudinal strain of $\mathrm{RV}$, Mean $\pm \mathrm{SD}$ of the RV global strain of patients group was [$12.60] \pm 2.17$ compared to [-19.77] \pm 2.29 of control group.

All these data was shown in the following table (5) and figure (1). 
Int. J. Curr. Res. Med. Sci. (2017). 3(5): 46-60

Table (1): demographic data of both cases and control group.

\begin{tabular}{|r|r|r|r|} 
Variables & Cases & Controls & P value \\
\hline Age & & & \\
\hline Mean \pm SD & $55.42 \pm 9.77$ & $51.5 \pm 7.86$ & 0.12 \\
\hline Median (range) & $57(35-75)$ & $50(35-67)$ & \\
\hline Gender & & & \\
\hline Females & $8(17.78 \%)$ & $8(40.00 \%)$ & 0.07 \\
\hline Males & $37(82.22 \%)$ & $12(60.00 \%)$ & \\
\hline
\end{tabular}

Table 2: comparison between two group according Echo dimensions

\begin{tabular}{l} 
Variables \\
LA Diameter \\
Mean \pm SD \\
Median (range) \\
\hline Aortic root diameter \\
Mean \pm SD \\
Median (range) \\
\hline LVEDD \\
\hline Mean \pm SD \\
\hline Median (range) \\
\hline LVESD \\
\hline Mean \pm SD \\
\hline Median (range)
\end{tabular}

\begin{tabular}{|c|c|c|}
\hline Cases & Controls & P value \\
\hline \begin{tabular}{c|c|}
$37.35 \pm 3.59$ \\
$36.5(32-43)$
\end{tabular} & 0.06 \\
\hline $\begin{array}{c}38.35 \pm 6.29 \\
28.45 \pm 4.93 \\
27(22-38)\end{array}$ & $\begin{array}{c}31.56 \pm 3.21 \\
31(23-37)\end{array}$ & 0.08 \\
\hline $49.6 \pm 1.95$ & $54.46 \pm 6.16$ & 0.004 \\
\hline $49(47-53)$ & $54(43-71)$ & \\
\hline $27.65 \pm 2.72$ & $37.13 \pm 6.53$ & 0.001 \\
\hline $27(24-34)$ & $37(26-58)$ & \\
\hline
\end{tabular}

Table (3): Comparison of cases and control as regards EF, FS, and TAPSE

\begin{tabular}{|l|c|c|c|}
\hline Variables & Cases & Controls & P value \\
\hline EF & & & \\
\hline Mean \pm SD & $58.02 \pm 8.47$ & $64.65 \pm 4.97$ & 0.003 \\
\hline Median (range) & $58(39-75)$ & $64(58-74)$ & \\
\hline FS & $31.2 \pm 5.98$ & $35.7 \pm 3.97$ & 0.003 \\
\hline Mean \pm SD & $30(18-45)$ & $34.5(31-43)$ & \\
\hline Median (range) & & & \\
\hline TAPSE & $22.4 \pm 2.6$ & $24.1 \pm 0.26$ & 0.02 \\
\hline Mean \pm SD & $22(16-28)$ & $24.5(1.9-2.8)$ & \\
\hline Median (range) & & & \\
\hline
\end{tabular}


Int. J. Curr. Res. Med. Sci. (2017). 3(5): 46-60

Table (4): Comparison of cases and control groups as regard TDI.

\begin{tabular}{|c|c|c|c|}
\hline Variables & Cases & Controls & $P$ value \\
\hline & \multicolumn{3}{|c|}{ Left ventricular later wall } \\
\hline $\begin{array}{l}\text { LV lat. wall Em } \\
\text { Mean } \pm \text { SD } \\
\text { Median (range) }\end{array}$ & $\begin{array}{c}9.66 \pm 3.11 \\
9.65(2.83-17.6)\end{array}$ & $\begin{array}{c}12.72 \pm 3.48 \\
12.87(6.35-17.4)\end{array}$ & 0.0008 \\
\hline $\begin{array}{l}\text { LV lat. wall Am } \\
\text { Mean } \pm \text { SD } \\
\text { Median (range) }\end{array}$ & $\begin{array}{c}8.62 \pm 3.03 \\
8.09(3.8-16.2)\end{array}$ & $\begin{array}{c}8.18 \pm 2.69 \\
7.51(4.29-15.7)\end{array}$ & 0.71 \\
\hline $\begin{array}{l}\text { LV lat. wall E/A ratio } \\
\text { Mean } \pm \text { SD } \\
\text { Median (range) }\end{array}$ & $\begin{array}{c}1.28 \pm 0.74 \\
1.04(0.43-4.63)\end{array}$ & $\begin{array}{c}1.69 \pm 0.72 \\
1.46(0.74-3.22)\end{array}$ & 0.009 \\
\hline $\begin{array}{l}\frac{\text { LV lat. wall Sm }}{\text { Mean } \pm \text { SD }} \\
\text { Median (range) }\end{array}$ & $\begin{array}{c}7.75 \pm 1.53 \\
7.7(5.07-10.8)\end{array}$ & $\begin{array}{c}8.88 \pm 2.05 \\
8.14(6.24-12.7)\end{array}$ & 0.02 \\
\hline & \multicolumn{3}{|c|}{ Left ventricular septal wall } \\
\hline $\begin{array}{l}\text { LV Septal wall Em } \\
\text { Mean } \pm \text { SD } \\
\text { Median (range) }\end{array}$ & $\begin{array}{c}6.26 \pm 1.89 \\
5.75(2.83-12.3)\end{array}$ & $\begin{array}{c}11.95 \pm 2.94 \\
11(8.4-16.9)\end{array}$ & $<0.0001$ \\
\hline $\begin{array}{l}\text { LV Septal wall Am } \\
\text { Mean } \pm \text { SD } \\
\text { Median (range) } \\
\end{array}$ & $\begin{array}{c}8.45 \pm 1.95 \\
8.09(4.8-12.9)\end{array}$ & $\begin{array}{c}7.73 \pm 1.38 \\
7.74(5.26-11.1)\end{array}$ & 0.15 \\
\hline $\begin{array}{l}\text { LV Septal wall E/A } \\
\text { ratio } \\
\text { Mean } \pm \text { SD } \\
\text { Median (range) }\end{array}$ & $\begin{array}{c}0.76 \pm 0.26 \\
0.69(0.40-1.57)\end{array}$ & $\begin{array}{c}1.62 \pm 0.62 \\
1.31(0.98-3.12)\end{array}$ & $<0.0001$ \\
\hline $\begin{array}{l}\text { LV Septal wall Sm } \\
\text { Mean } \pm \text { SD } \\
\text { Median (range) } \\
\end{array}$ & $\begin{array}{c}7.16 \pm 1.17 \\
7.2(5.17-9.3)\end{array}$ & $\begin{array}{c}8.99 \pm 1.83 \\
8.53(6.5-12.5)\end{array}$ & $<0.0001$ \\
\hline & \multicolumn{3}{|c|}{ Right ventricular free wall } \\
\hline $\begin{array}{l}\mathrm{RV} \text { free wall Em } \\
\text { Mean } \pm \text { SD } \\
\text { Median (range) } \\
\end{array}$ & $\begin{array}{c}9.08 \pm 3.99 \\
8.36(5.17-30.1)\end{array}$ & $\begin{array}{c}13.35 \pm 4.81 \\
11.75(7.85-28.5)\end{array}$ & 0.0004 \\
\hline $\begin{array}{l}\text { RV free wall Am } \\
\text { Mean } \pm \text { SD } \\
\text { Median (range) }\end{array}$ & $\begin{array}{c}13.64 \pm 4.15 \\
12.8(6.34-31.4)\end{array}$ & $\begin{array}{c}12.70 \pm 4.07 \\
11.55(8.09-24.6)\end{array}$ & 0.40 \\
\hline $\begin{array}{l}\text { RV free wall E/A ratio } \\
\text { Mean } \pm \text { SD } \\
\text { Median (range) } \\
\end{array}$ & $\begin{array}{c}0.67 \pm 0.20 \\
0.65(0.39-1.72)\end{array}$ & $\begin{array}{c}1.15 \pm 0.51 \\
1.04(0.37-2.26)\end{array}$ & $<0.0001$ \\
\hline $\begin{array}{l}\mathrm{RV} \text { free wall Sm } \\
\text { Mean } \pm \text { SD } \\
\text { Median (range) }\end{array}$ & $\begin{array}{l}11.34 \pm(1.80) \\
11.1(7.3-15)\end{array}$ & $\begin{array}{c}13.63 \pm 1.32 \\
13.4(11.8-16.9)\end{array}$ & $<0.0001$ \\
\hline
\end{tabular}


Int. J. Curr. Res. Med. Sci. (2017). 3(5): 46-60

Table (5): Comparison of cases and control groups as regard global longitudinal strain of Speckle tracking

\begin{tabular}{r|c|c|c|}
\hline Variables & Cases & Controls & \multicolumn{1}{c|}{ P value } \\
\hline LV G.L. strain & & & \\
\hline Mean \pm SD & {$[-12.59] \pm 2.94$} & {$[-19.91] \pm 2.04$} & $<0.0001$ \\
\hline Median (range) & {$[-12.21]([-19.32]:[-6.2])$} & {$[-19.62]([-23.7]:[-16.34)$} & \\
\hline RV G.L. strain & & & \\
\hline $\begin{array}{r}\text { Mean } \pm \text { SD } \\
\text { Median (range) }\end{array}$ & {$[-11.8]([-17.88]:[-8.26])$} & {$[-19.23]([-24.2]:[-16.9]$} & \\
\hline
\end{tabular}

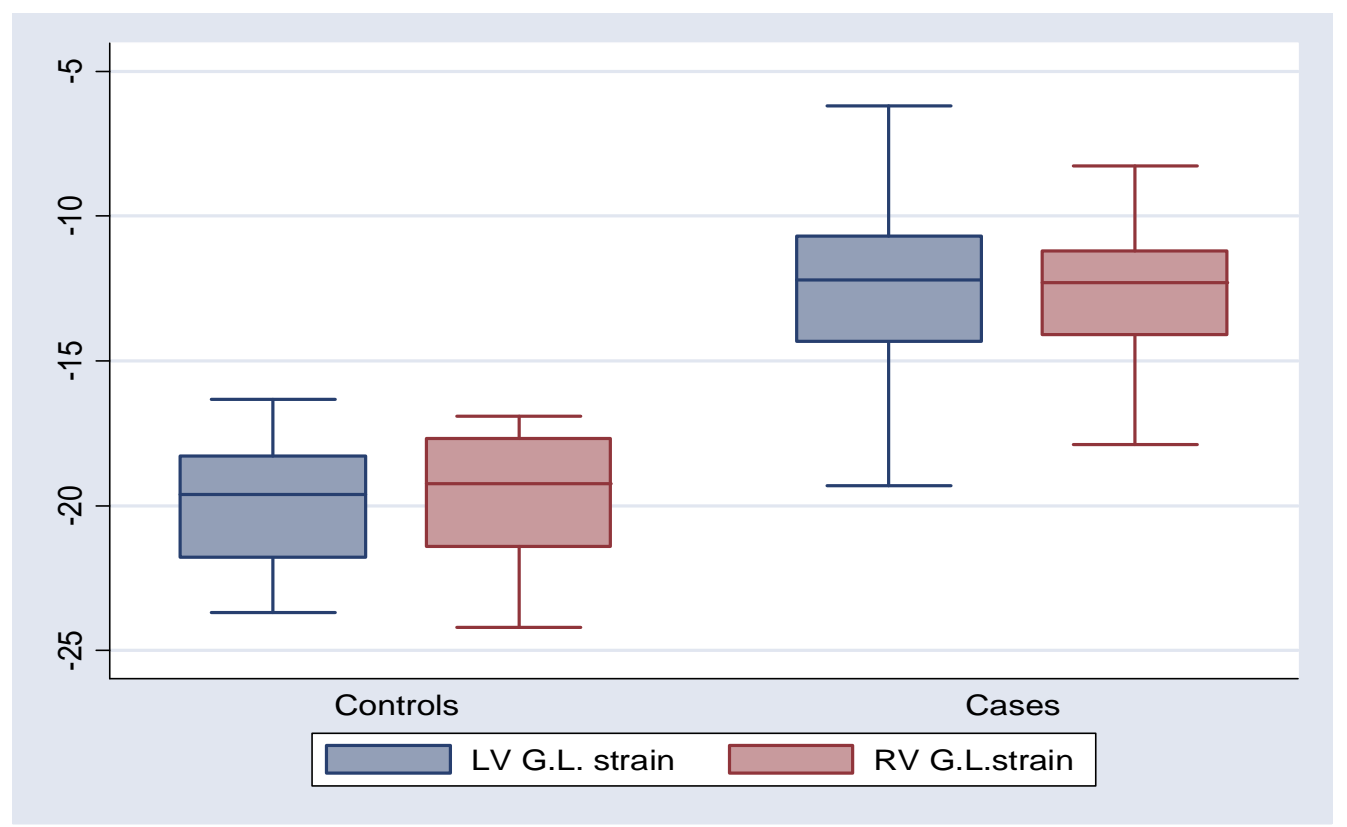

Fig (1) Global RV and LV strain of patients versus control group

\section{1- According the presence or absence of} significant proximal RCA stenosis the patients were divided into two sub group :-

-Group (A) which represents 17 patients with proximal RCA stenosis, one female and 16 males with Mean age $56 \pm 10.55$ years.

-Group (B) which represents 28 patients without proximal RCA stenosis, 7 female and 21 males

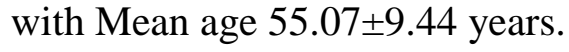

a) Two groups matching together according to demographic data (age, sex), history of DM and hypertension, and all this data of both two groups were shown in table (6).

\section{b) General Echo findings:-}

1-Echo dimensions: LV dimensions (LVEDD \&LVESD) are significantly larger in patients with proximal RCA stenosis (group A) compared to group (B), Mean \pm SD of the LVEDD is 55.88 \pm 5.26 in group (A) compared to Mean \pm SD of the LVEDD is $53.6 \pm 5.04$ in group (B), Mean \pm SD of the LVESD is $38.7 \pm 4.94$ in group (A) compared to Mean $\pm \mathrm{SD}$ of the LVESD is $36.17 \pm 4.2$ in group $(\mathrm{B})$.

On the other hand there is no significant difference between two groups as regards LA \& aortic root diameters, all of this diameters showing in the following table (7). 


\section{2- Echo findings according to ventricular function:}

i. LV function (EF\&FS) was impaired in patients with proximal RCA (group A) than patients without proximal RCA (group B) as the following: EF\% were (Mean \pm SD 54.88 \pm 5.99 ) in group (A) compared to (Mean \pm SD 59.9 \pm 9.25 ) in group (B), FS in group A were (Mean \pm SD28.41 \pm 3.54 ) compared to (Mean \pm SD $32.89 \pm 6.55$ ) in group B.

ii. RV function: RV systolic function which assessed by TAPSE was significantly better in patients without proximal RCA compared to patients with proximal RCA (group A) (Mean \pm SD SD2.34 \pm 0.22 ) in group (B) compared to (Mean $\pm 2.06 \pm 0.24$ ) in group (A), All these findings are shown in table (8).

c) TDI by echo: Systolic and diastolic functions of the RV were significantly lower in patients with proximal RCA stenosis ( group A) compared to patients without proximal RCA ( group B) according to atrial diastolic velocity (Am), E/A ratio and peak systolic velocity $(\mathrm{Sm})$ of the $\mathrm{RV}$ free wall, also there significant increase of peak early diastolic velocity (Em) of lateral wall of LV in group (A) more than group (B).

On the contrary, there were no significant differences between two groups as regards, RV free wall $(\mathrm{Em})$. All of these data shown in the table (9).

d) Speckle tracking by 2D- echo: The RV systolic function was significantly better in patients without proximal RCA stenosis (group B) than patients with proximal RCA stenosis (group A) according to global longitudinal strain of RV, Mean \pm SD of the RV global strain of group (B) was $[-13.08] \pm 2.03$ compared to [-10.8724] \pm 2.23 of group(A).

All of these data shown in the table (10) and figure (2).

Table (6) Comparison between patients with and without proximal RCA as regard demographic data, DM and HTN.

\begin{tabular}{|l|c|c|c|}
\hline Variables & Proximal RCA & No proximal RCA & P value \\
\hline Age & & & \\
\hline Mean \pm SD & $56 \pm 10.55$ & $55.07 \pm 9.44$ & 0.76 \\
Median (range) & $56(40-75)$ & $57.5(35-72)$ & \\
\hline $\begin{array}{l}\text { Gender } \\
\text { Females } \\
\text { Males }\end{array}$ & $1(5.88 \%)$ & $7(25.00 \%)$ & 0.13 \\
\hline $\begin{array}{l}\text { History of hypertension } \\
\text { No }\end{array}$ & $9(94.12 \%)$ & $21(75.00 \%)$ & \\
Yes & $8(47.06 \%)$ & $14(50.00 \%)$ & 0.85 \\
\hline History of DM & $14(50.00 \%)$ & \\
No & $10(58.82 \%)$ & $19(67.86 \%)$ & 0.54 \\
Yes & $7(41.18 \%)$ & $9(32.14 \%)$ & \\
\hline
\end{tabular}


Int. J. Curr. Res. Med. Sci. (2017). 3(5): 46-60

Table (7): comparison between two groups as regards Echo diameters.

\begin{tabular}{|l|c|c|c|}
\hline Variables & With proximal RCA & Without proximal RCA & P value \\
\hline \begin{tabular}{l|c|c} 
Left atrial Diameter \\
Mean \pm SD
\end{tabular} & $37.9 \pm 3.99$ & $38.6 \pm 7.4$ & 0.06 \\
Median (range) & $37(32-46)$ & $39(22-52)$ & \\
\hline Aortic root diameter & $31.6 \pm 2.51$ & $31.5 \pm 3.57$ & 0.08 \\
\hline Mean \pm SD & $31(28-37)$ & $31(23-37)$ & \\
\hline Median (range) & $55.88 \pm 5.26$ & & \\
\hline LVEDD & $55(45-71)$ & $53.6 \pm 5.04$ & \\
Mean \pm SD & & $52.5(43-67)$ & \\
Median (range) & $38.7 \pm 4.94$ & $36.17 \pm 4.2$ & 0.04 \\
\hline LVESD & $38(29-58)$ & $33(26-50)$ & \\
\hline Mean \pm SD & & & \\
\hline Median (range) & & &
\end{tabular}

Table (8) Comparison between group (A) and group (B) as regard EF, FS and TAPSE.

\begin{tabular}{|l|c|c|c|}
\hline \multicolumn{1}{|c|}{ Variables } & Proximal RCA & No proximal RCA & P value \\
\hline EF & $54.88 \pm 5.9$ & $59.93 \pm 9.25$ & 0.03 \\
Mean \pm SD & $57(39-61)$ & $59(40-75)$ & \\
Median (range) & & & \\
\hline FS & $28.41 \pm 3.54$ & $32.89 \pm 6.55$ & 0.01 \\
\hline Mean \pm SD & $29(18-32)$ & $31.5(22-45)$ & \\
\hline Median (range) & & & \\
\hline & $2.06 \pm 0.24$ & $2.34 \pm 0.22$ & 0.0002 \\
\hline TAPSE & $2.1(1.6-2.46)$ & $2.31(1.9-2.8)$ & \\
\hline Mean \pm SD & & & \\
\hline Median (range) & & & \\
\hline
\end{tabular}


Int. J. Curr. Res. Med. Sci. (2017). 3(5): 46-60

Table (9) comparison between group (A) and group (B) as regard TDI Echo data.

\begin{tabular}{|c|c|c|c|}
\hline Variables & proximal RCA & No Proximal RCA & P value \\
\hline \multicolumn{4}{|c|}{ Left ventricular later wall } \\
\hline LV lat. wall Em & \multirow{3}{*}{$\begin{array}{c}11.13 \pm 2.77 \\
10.6(6.1-17.6)\end{array}$} & \multirow{3}{*}{$\begin{array}{c}8.77 \pm 2.99 \\
8.98(2.83-16.7)\end{array}$} & \multirow{3}{*}{0.01} \\
\hline Mean \pm SD & & & \\
\hline Median (range) & & & \\
\hline LV lat. wall Am & \multirow{3}{*}{$\begin{array}{c}8.99 \pm 3.73 \\
7.51(3.8-16.2)\end{array}$} & \multirow{3}{*}{$\begin{array}{c}8.39 \pm 2.56 \\
8.15(4.19-13.5)\end{array}$} & \multirow{3}{*}{0.87} \\
\hline Mean \pm SD & & & \\
\hline Median (range) & & & \\
\hline LV lat. wall E/A ratio & \multirow{3}{*}{$\begin{array}{c}1.51 \pm 0.98 \\
1.23(0.63-4.63)\end{array}$} & \multirow{3}{*}{$\begin{array}{c}1.13 \pm 0.53 \\
0.94(0.43-2.33)\end{array}$} & \multirow{3}{*}{0.18} \\
\hline Mean \pm SD & & & \\
\hline Median (range) & & & \\
\hline LV lat. wall Sm & \multirow{3}{*}{$\begin{array}{c}7.90 \pm 1.43 \\
8.38(5.8-10.3)\end{array}$} & \multirow{3}{*}{$\begin{array}{c}7.67 \pm 1.60 \\
7.46(5.07-10.8)\end{array}$} & \multirow{3}{*}{0.63} \\
\hline Mean \pm SD & & & \\
\hline Median (range) & & & \\
\hline \multirow{2}{*}{\multicolumn{4}{|c|}{ Left ventricular septal wall }} \\
\hline LV Septal wall Em & & & \multirow{3}{*}{0.23} \\
\hline Mean \pm SD & \multirow{2}{*}{$\begin{array}{c}6.69 \pm 2.17 \\
5.75(4.09-12.3)\end{array}$} & \multirow{2}{*}{$\begin{array}{c}5.99 \pm 1.69 \\
5.7(2.83-9.65)\end{array}$} & \\
\hline Median (range) & & & \\
\hline LV Septal wall Am & \multirow{3}{*}{$\begin{array}{c}8.59 \pm 2.15 \\
8.09(4.8-12.9)\end{array}$} & \multirow{3}{*}{$\begin{array}{c}8.36 \pm 1.84 \\
8.05(5.85-12.5)\end{array}$} & \multirow{3}{*}{71} \\
\hline Mean \pm SD & & & \\
\hline Median (range) & & & \\
\hline LV Septal wall E/A ratio & \multirow{3}{*}{$\begin{array}{c}0.80 \pm 0.27 \\
0.70(0.49-1.57)\end{array}$} & \multirow{3}{*}{$\begin{array}{c}0.74 \pm 0.25 \\
0.68(0.40-1.35)\end{array}$} & \multirow{3}{*}{0.58} \\
\hline Mean \pm SD & & & \\
\hline Median (range) & & & \\
\hline LV Septal wall Sm & \multirow{3}{*}{$\begin{array}{c}7.11 \pm 1.20 \\
7.05(5.17-9.2)\end{array}$} & \multirow{4}{*}{$\begin{array}{l}\quad 7.19 \pm 1.17 \\
7.21(5.17-9.3) \\
\text { vall }\end{array}$} & \multirow{3}{*}{0.82} \\
\hline Mean \pm SD & & & \\
\hline Median (range) & & & \\
\hline & Right ventricular & & \\
\hline RV free wall Em & & & \\
\hline Mean \pm SD & $8.42 \pm 2.34$ & $9.49 \pm 4.71$ & 0.39 \\
\hline Median (range) & $7.85(5.56-13.5)$ & $8.53(5.17-30.1)$ & \\
\hline RV free wall Am & & & \\
\hline Mean \pm SD & $11.90 \pm 2.86$ & $14.70 \pm 4.49$ & 0.03 \\
\hline Median (range) & $11.2(6.34-17.3)$ & $14.35(9.52-31.4)$ & \\
\hline $\mathrm{RV}$ free wall E/A ratio & & & \\
\hline Mean \pm SD & $0.71 \pm 0.10$ & $0.65 \pm 0.25$ & 0.02 \\
\hline Median (range) & $0.68(0.59-0.89)$ & $0.61(0.39-1.72)$ & \\
\hline $\mathrm{RV}$ free wall $\mathrm{Sm}$ & & & \\
\hline Mean \pm SD & $10.41 \pm 1.60$ & $11.91 \pm 1.70$ & 0.005 \\
\hline Median (range) & $10.5(7.3-12.8)$ & $11.85(9-15)$ & \\
\hline
\end{tabular}


Table(10) : comparison between two groups as regard global longitudinal strain of Speckle tracking.

\begin{tabular}{c|c|c|c|}
\hline Variables & Proximal RCA & No proximal RCA & P value \\
\hline LV G.L. strain & & & 0.33 \\
\hline Mean \pm SD & {$[-13.14] \pm 3.09$} & {$[-12.26] \pm 2.85$} & \\
\hline Median (range) & {$[-13.41]([-19.32]:[-8.3]$} & {$[-12.17]([-17.11]:[-6.2]$} & \\
\hline $\begin{array}{c}\text { RV G.L. strain } \\
\text { Mean } \pm \text { SD } \\
\text { Median (range) }\end{array}$ & {$[-11.34]([-16.61]:[-8.26])$} & {$[-13.31]([-17.88]:[-9.33]$} & \\
\hline
\end{tabular}

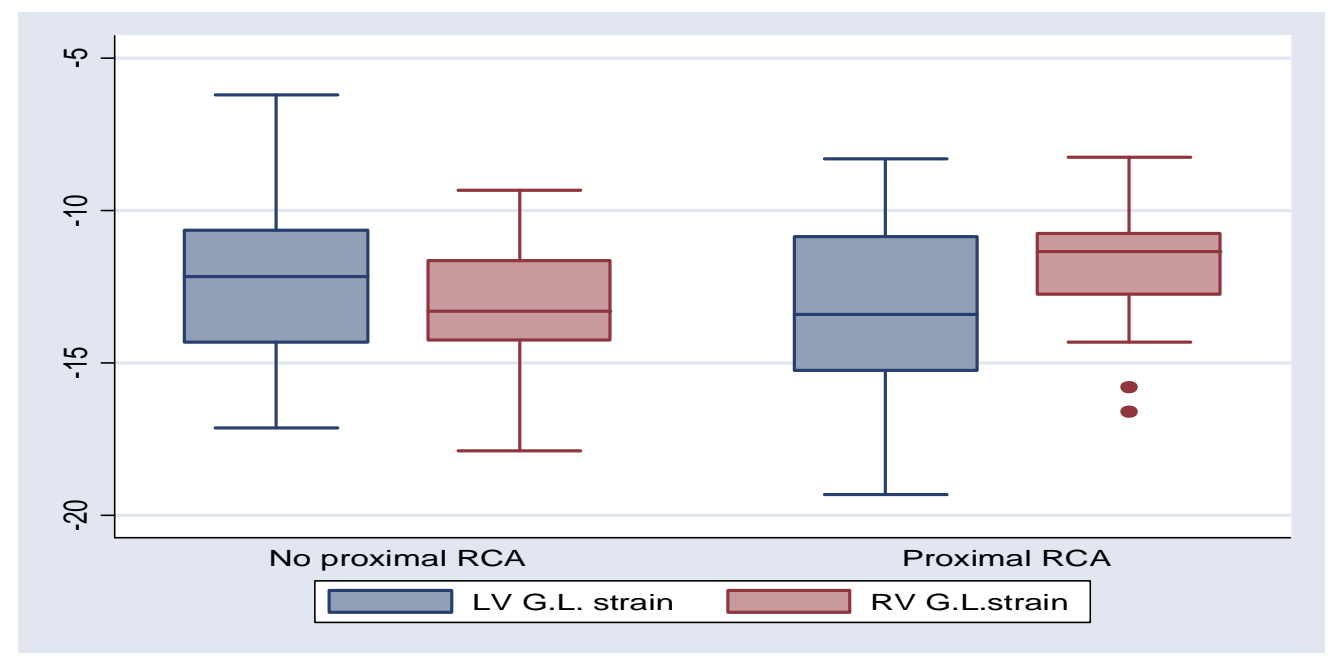

Figure (2): comparison between two groups as regard global longitudinal strain of Speckle tracking by 2Decho

\section{Discussion}

Echo assessment of the right side of the heart is gaining importance in current clinical practice and research with guidelines published specifically to address this purpose (5). This is because of growing evidence of its effects on clinical outcome, morbidity and mortality of several cardiac conditions (6). Evaluation of the RV function has a very significant role in the outcome of patients with MI, especially in those with RVMI. Imaging of the RV is difficult due to its complex crescent-shaped structure, trabeculation. TDI are gaining importance in the assessment of RV performance (7). The main findings of present study were that patients with acute inferior wall MI had significantly lower values of RV systolic and diastolic function (manifested by significant reduction of TAPSE, TDI velocities, global longitudinal strain by speckle tracking) in patients compared to control persons. As regard the RV systolic function which assessed by TAPSE, The current study was concordant with Katsuhisa, et al, who Quantifying longitudinal $\mathrm{RV}$ dysfunction in patients with old MI by using speckle-tracking strain echo (8) and Gorter et al, who assessed the Right ventricular function after acute myocardial infarction treated with primary percutaneous coronary intervention (from the glycometabolic intervention as adjunct to primary percutaneous coronary intervention in STsegment elevation myocardial infarction III trial and concluded that TAPSE was reduced in patients with acute inferior wall MI compared to control group (9). On the other hand the present study disagreed with Lang et al, who reported the Recommendations for Cardiac Chamber Quantification by Echo in Adults, and concluded that the cut off value for TAPSE is $\leq 17 \mathrm{~mm}$ in RV dysfunction, our study concluded the cut off 
values was $\leq 22 \mathrm{~mm}$, that contrary may be explained by some of our patients undergone to reperfusion therapy as there is a possibility of recovery of $\mathrm{RV}$ function that before echo assessment and also delayed echo examination for some cases after spontaneous recanalization of affected coronary artery (10). According to assessment of RV systolic function by pulsed wave TDI the present study agreed with Witt and colleague, who investigated the tricuspid annular velocity assessed by TDI as a marker of RV involvement in the acute and late phase after a first ST elevation MI, and showed a similar diagnostic accuracy of TDI Sm wave of tricuspid annulus in prediction of RV dysfunction, and significantly impaired in patients group compared to control persons (11). The present study was also concordant with Martin et al who studied the Echo assessment of global longitudinal RV function in patients with an acute inferior ST elevation MI and proximal RCA occlusion ,and reported a significant decrease in TDI- based myocardial velocities of the RV has a global effect following acute MI (12). Our study demonstrated that a cut-off value of TDI systolic velocity $\mathrm{Sm}=11.34 \mathrm{~cm} / \mathrm{s}$, this is concordant with Zabroska et al, who studied the diagnostic and prognostic value of right ventricular velocities in inferior myocardial infarction treated with primary PCI, they reported that cut-off values of TDI Sm indicating a functional RV impairment < $12 \mathrm{~cm} / \mathrm{s}$ in different clinical situations (13). On the other hand our study disagreed with Lang et al, who reported the Recommendations for Cardiac Chamber Quantification by Echo in Adults, and concluded that the cut off value for $\mathrm{Sm}$ is $9.5 \mathrm{~cm} / \mathrm{s}$ in RV dysfunction, our study concluded the cut off value was $11.34 \mathrm{~cm} / \mathrm{s}$, that contrary may be explained by some of our patients undergone to reperfusion therapy as there is a possibility of recovery of $\mathrm{RV}$ function before echo assessment and also delayed echo examination for some cases after spontaneous recanalization of affected coronary artery (14).

As regard diastolic dysfunction of $\mathrm{RV}$ which demonstrated by the current study based on TDI, the early diastolic annular velocities (Em), showed significant decrease in patients with acute inferior wall MI compared to control subjects, with no significant difference between two groups according to late diastolic velocity(Am). This finding was agreed with the study of Nicholaos et al, who assessed the TDI of the Tricuspid Annulus and Myocardial Performance Index in the Evaluation of RV Involvement in the Acute and Late Phase of a First Inferior MI and demonstrated significant decrease of systolic and diastolic velocity in patients group compared to control persons, with no significant difference as regard late diastolic velocity (Am) (15). Again the present study also agreed with Kidawa et al, who investigated the Real-time 3D echo and TDI in the assessment of RV systolic function in patients with RV MI, they had reported that patients with diastolic dysfunction on TDI has significant reduction of $\mathrm{Em}$ in patients group compared to control group but the late peak diastolic velocity (Am) was insignificantly reduced (16).

As regard global longitudinal strain for assessment of RV function by 2D speckle tracking, the current study concordant with Horton et al, who studied the Assessment of the RV by echo: a primer for cardiac sonographers (17) and Kossaify et al, who studied the echocardiographic assessment of the right ventricle, from the conventional approach to speckle tracking and three dimensional imaging, and insights into the "Right Way" to explore the forgotten chamber and they found significant decrease of global longitudinal ventricular strain in patients group compared to control group (18). The current study also agreed with Katsuhisa et al, who Quantifying longitudinal RV dysfunction in patients with old MI by using speckle-tracking strain echo, and concluded that global longitudinal RV strain was reduced in patients with acute inferior wall MI and longitudinal function mainly reflects global RV systolic function (19). Again The present study was also concordant with Martin et al, who studied the Echo assessment of global longitudinal RV function in patients with an acute inferior ST elevation MI and proximal RCA occlusion, and they demonstrated that a significant decrease in strain/strain rate values of the $\mathrm{RV}$ has a global effect following acute MI (20). Our study also agreed with Lang et al, who reported the Recommendations for Cardiac Chamber 
Quantification by Echo in Adults, and concluded that global longitudinal strain lower than -20 indicates RV systolic dysfunction (21). As regard comparison between patients with proximal RCA lesion an patients without proximal RCA lesion, the present study agreed with Alam et al, who studied the RV function in patients with first inferior MI: assessment by tricuspid annular motion and tricuspid annular velocity, they found there is significant impairment of TAPSE in patients with proximal RCA lesion more than patients without proximal RCA lesion (22). Our study also was concordant with Gopalan et al, who studied the echo assessment of RV function in inferior wall MI and angiographic correlation to proximal RCA stenosis, and concluded that TAPSE was significantly lower in patients with proximal RCA lesion and both two groups of patients according to presence or absence of proximal RCA stenosis had no significant differences in baseline variables like age, sex, prevalence of hypertension and diabetes (23). On the other hand the present study disagreed with Rudski et al, who demonstrated the guidelines for the Echo Assessment of the Right Heart in Adults, they concluded that cut off value of TAPSE was less than $17 \mathrm{~mm}$ indicate $\mathrm{RV}$ dysfunction, but our study demonstrate $\leq 20 \mathrm{~mm}$ cut off value of TAPSE was predicted proximal RCA lesion (24), and disagreed with El Sebaie et al, who assessed the right ventricular echocardiographic parameters for prediction of proximal right coronary artery lesion in patients with inferior wall myocardial infarction who found that there is no significant difference according to right ventricular function which assessed by TAPSE in patients with or without proximal RCA lesion that may be due to echo assessment of RV function in both two previous study was done before reperfusion therapy but in our study some of our patients undergone to reperfusion therapy as there is a possibility of recovery of $\mathrm{RV}$ function that before echo assessment (25). According to TDI assessment of $\mathrm{RV}$ function for patients with or without proximal RCA lesion the present study agreed with Ozdemir et al, who studied the new parameters in identification of RV MI and proximal RCA lesion, they concluded that peak velocity of $\mathrm{RV}$ free wall $(\mathrm{Sm})$ is $\leq 10.41 \mathrm{~cm} / \mathrm{s}$ predicted proximal
RCA lesion with $64.7 \%, 75 \%, 77.8 \%$ and $61.1 \%$ sensitivity and specificity, negative predictive value and positive predictive value respectively (26). Current study was also concordant with Mukhaini et al, who studied the Assessment of RV diastolic function by TDI in patients with acute RV MI, and proved that RV diastolic function was significantly lower in patients with proximal RCA lesion compared to patients without proximal RCA lesion (27). Again the present study also was agreed with Kakouros et al, who studied the Tissue Doppler imaging of the tricuspid annulus and myocardial performance index in the evaluation of right ventricular involvement in the acute and late phase of a first inferior myocardial infarction, how found that the peak systolic velocity $\left(S^{\prime}\right)$ of the tricuspid annulus was significantly lower in patients with proximal RCA lesion (28). As regard global longitudinal strain of RV in patients with or without proximal RCA lesion, the current study agreed with Chang et al, who study the changes in right ventricular free wall strain in patients with CAD involving the RCA, they demonstrated global longitudinal strain of patients with proximal RCA versus non proximal RCA are $-13.65 \pm 3.83 \%$ versus -15.69 $\pm 4.37 \%$ respectively, and proved that the systolic function of the RV which assessed by global longitudinal strain was decreased significantly in patients with proximal RCA stenosis compared to non proximal RCA stenosis (29).

Limitations: This study involved a relatively small number of patients at a single center, so future studies of larger numbers of patients are required to determine the actual usability echocardiography of ventricular dysfunction and prediction of proximal RCA stenosis .

Before and after the reperfusion therapy was unclear, Echocardiographic assessment should ideally be performed before any reperfusion strategy as there is a possibility of recovery of RV function. But it was considered unethical to delay reperfusion for echocardiographic assessment.

the pre-existing RV systolic dysfunction could not be excluded. Because RV systolic function can be affected by various conditions, there might be the possibility of the presence of RV systolic 
dysfunction by other causes than the occlusion of RV branches. However, in the current study we tried to avoid this limitation by choose patients with first episode of acute inferior wall infarction and exclude all patients suffering of any causes of $\mathrm{RV}$ dysfunction as COPD.

A prospective study with a larger number of patients and a well-designed protocol will be needed to confirm the correlation and the clinical impact of impaired RV function in patients with acute inferior MI.

\section{Conclusion}

Tissue Doppler and strain echocardiography provides additional information to conventional echocardiography.

The reduced peak systolic velocity and reduced peak early diastolic velocity and GLS seems to be an expression of globally reduced ventricular systolic and diastolic functions in patients with acute inferior myocardial infarction.

Echocardiographic assessment of various parameters of RV function showed significant difference between groups with or without proximal RCA lesion.

Tissue Doppler systolic annular velocity and global longitudinal strain by $2 \mathrm{D}$-speckle tracking are easy to perform and useful in predicting proximal RCA as infarct related artery.

Recommendation: Assessment of ventricular function specially right ventricle is complex but is an essential component of every echocardiographic examination.

RV assessment adds important diagnostic and prognostic information.

Further study focusing on echocardiographic measurements after reperfusion treatment to investigate speed of recovery.

\section{References}

1.Inohara T, Kohsaka S, Fukuda K, Menon V. The challenges in the management of right ventricular infarction. Eur Heart $\mathbf{J}$ Acute Cardiovasc Care. Sep 2(3):226-34 ; 2013.

2.Takamura T, Dohi K, Onishi K, Tanabe M, Sugiura E, Nakajima $H$, Ichikawa $K$, Nakamura M, Nobori T, Ito $M$ : Left ventricular contraction-relaxation coupling in normal, hypertrophic, and failing myocardium quantified by speckle-tracking global strain and strain rate imaging. $J$ Am Soc Echocardiogr, 23:747-754;2010.

3.Inohara T, Kohsaka S, Fukuda K, Menon V. The challenges in the management of right ventricular infarction. Eur Heart $\mathrm{J}$ Acute Cardiovasc Care. Sep 2(3):226-34; 2013.

4.Marwick TH. Measurement of strain and strain rate by echocardiography: ready for prime time? J Am Coll Cardiol. Apr 47(7):1313-27 ; 2006.

5.Rudski G, Lai W, Hua L, Handschumacher M, Chandrasekaran K, Solomon D. Guidelines for the Echocardiographic Assessment of the Right Heart in Adults: A Report from American Society of Echocardiography Endorsed by the European Association of Echocardiography, a registered branch of the European Society of Cardiology, and the Canadian Society of Echocardiography. J Am Soc Echocardiogr. 23: 685-713; 2010.

6.Nikdoust F, Tabatabaei SA, Shafiee A, Mostavia A,Mohamadi M, Mohamadi S. the effect of elective percutaneous coronary intervention of the right coronary artery on right ventricular function. Int Cardiovasc Res J. 8(4):148-51; 2014.

7.Kidawa M, Chiz' yn' ski1 K, Zielin'ska M, Kasprzak J, Krzeminska-Pakula M. Realtime 3D echocardiography and tissue Doppler echocardiography in the assessment of right ventricle systolic function in patients with right ventricular myocardial infarction. European Heart Journal - Cardiovascular Imaging 14, 1002-1009; 2013. 
8.Katsuhisa K, Kaoru D, Muneyoshi T, Yuichi S, Kiyotaka W, Emiyo S, Naoto K, Shiro N, Hiroshi N, Tomomi Y, Katsuya, Mashio N, Tsutomu N, Masaaki I. Quantifying longitudinal right ventricular dysfunction in patients with old myocardial infarction by using speckle-tracking strain echocardiography. Cardiovascular Ultrasound. 27 June 11:23; 2013.

9.Gorter TM, Lexis CP, Hummel YM, Lipsic E, Nijveldt R, Willems TP, van der Horst IC, van melle JP, van Veldhuisen DJ. Right ventricular function after acute myocardial infarction treated with primary percutaneous coronary intervention(from the glycometabolic intervention as adjunct to primary percutaneous coronary intervention in STsegment elevation myocardial infarction III trial). Am J Cardiol. 118(3): 338-44; 2016.

10. Lang $\mathbf{M}$, Badano L, VictorMor-Avi, Anderson A, Laura E, Frank A, Elyse F, Steven A, Tatiana K, Patrizio L, Denisa M, Michael H, Ernst R, Lawrence R, Kirk T, Wendy $\mathbf{T}$, Jens-Uwe $\mathbf{V}$. Recommendations for Cardiac Chamber Quantification by Echocardiography in Adults: An Update from the American Society of Echocardiography and the European Association of Cardiovascular Imaging. European Heart Journal - Cardiovascular Imaging. 16, 233271; 2015.

11. Witt N, Alam M, Svensson L. Tricuspid annular velocity assessed by doppler tissue imaging as a marker of right ventricular involvement in the acute and late phase after a first ST elevation myocardial infarction. Echocardiography 27(2):139-145; 2010

12. Martin H, Tomas S, David H, Martin K, Zbynek T, Jana Z, Jan P, Albert L, Ales S, Milos T. Echocardiographic assessment of global longitudinal right ventricular function in patients with an acute inferior ST elevation myocardial infarction and proximal right coronary artery occlusion. Int $\mathrm{J}$ Cardiovasc Imaging. 31:497-507; 2015.

13. Zabroska B, Makwoska E, Pilicowska E, Maciejewski P, Bednarz B, Wasek W, Stec S, Budaj A. diagnostic and prognostic value of right ventricular velocities in inferior myocardial infarction treated with primary PCI. Kardiol Pol. 69(10):1054-61; 2011.

14. Lang M, Badano L, VictorMor-Avi, Anderson A, Laura E, Frank A, Elyse F, Steven A, Tatiana K, Patrizio L, Denisa M, Michael H, Ernst R, Lawrence R, Kirk T, Wendy T, Jens-Uwe V. Recommendations for Cardiac Chamber Quantification by Echocardiography in Adults: An Update from the American Society of Echocardiography and the European Association of Cardiovascular Imaging. European Heart Journal - Cardiovascular Imaging. 16, 233$271 ; 2015$.

15. Nicholaos K, Stavros K, John L, Ioannis R and Dennis C. Tissue Doppler Imaging of the Tricuspid Annulus and Myocardial Performance Index in the Evaluation of Right Ventricular Involvement in the Acute and Late Phase of a First Inferior Myocardial Infarction. Echocardiography. 311:319-9; 2011.

16. Kidawa M, Chiz'yn' ski1 K, Zielin'ska M, Kasprzak J, Krzeminska-Pakula M. Realtime 3D echocardiography and tissue Doppler echocardiography in the assessment of right ventricle systolic function in patients with right ventricular myocardial infarction. European Heart Journal - Cardiovascular Imaging 14, 1002-1009; 2013.

17. Horton K, Meece RW, Hill JC. Assessment of the right ventricle by echocardiography: a primer for cardiac sonographers. J Am Soc Echocardiogr 22:776e92; 2009.

18. Kossaify A. Echocardiographic assessment of the right ventricle, from the conventional approach to speckle tracking and three dimensional imaging, and insights into the "Right Way" to explore the forgotten chamber. Clin Med Insights Cardiol. 9:65-75; 2015.

19. Katsuhisa K, Kaoru D, Muneyoshi T, Yuichi S, Kiyotaka W, Emiyo S, Naoto K, Shiro N, Hiroshi N, Tomomi Y, Katsuya, Mashio N, Tsutomu N, Masaaki I. Quantifying longitudinal right ventricular dysfunction in patients with old myocardial infarction by using speckle-tracking strain echocardiography. Cardiovascular Ultrasound. 27 June 11:23; 2013. 
20. Martin H, Tomas S, David H, Martin K, Zbynek T, Jana Z, Jan P, Albert L, Ales S, Milos T. Echocardiographic assessment of global longitudinal right ventricular function in patients with an acute inferior ST elevation myocardial infarction and proximal right coronary artery occlusion. Int $\mathrm{J}$ Cardiovasc Imaging. 31:497-507; 2015.

21. Lang M, Badano P, Mor-Avi V, Afi lalo J, Armstrong A, Ernande L. Recommendations for cardiac chamber quantification by echocardiography in adults: an update from the American Society of Echocardiography and the European Association of Cardiovascular Imaging. J Am Soc Echocardiogr. 28:1-39.e; $14 ; 2015$.

22. Alam M, Wardell J, Andersson E. Right ventricular function in patients with first inferior myocardial infarction: assessment by tricuspid annular motion and tricuspid annular velocity. Am Heart J. 139:710e715; 2000.

23. Gopalan N, Deepak R, Deepak N, Vellani H, Desabandhu V, Kader M, Kadangot $B$. Echocardiographic assessment of right ventricular function in inferior wall myocardial infarction and angiographic correlation to proximal right coronary artery stenosis. Indian heart journal. 65- 522 e 5 28; 2013.

24. Rudski G, Lai W, Hua L, Handschumacher D, Chandrasekaran K, Solomon D. Guidelines for the Echocardiographic Assessment of the Right Heart in Adults: A Report from American Society of Echocardiography Endorsed by the European Association of Echocardiography, a registered branch of the European Society of Cardiology, and the Canadian Society of Echocardiography. J Am Soc Echocardiogr. 23: 685-713; 2010.

25. El Sebaie MH, El khateeb O. Right ventricular echocardiographic parameters for prediction of proximal right coronary artery lesion in patients with inferior wall myocardial infarction. J Saudi Heart Assoc. 28(2):73-80; 2016.

26. Ozdemir K, Altunkeser B, Ic li A. New parameters in identification of right ventricular myocardial infarction and proximal right coronary artery lesion. Chest 124:219-226; 2003.

27. Mukhaini M, Prashanth P, Abdulrehman S. Assessment of right ventricular diastolic function by tissue Doppler imaging in patients with acute right ventricular myocardial infarction. Echocardiography. 27:539e543; 2010.

28. Kakouros N, Stavros K, John L, Ioannis R and Dennis C. Tissue Doppler Imaging of the Tricuspid Annulus and Myocardial Performance Index in the Evaluation of Right Ventricular Involvement in the Acute and Late Phase of a First Inferior Myocardial Infarction. Echocardiography.311:319-9; 2011.

29. Chang T, Tsai C, Liu W, Lee H, Chen Y, Li H, Tsai M. Changes in right ventricular free wall strain in patients with coronary artery disease involving the right coronary artery. $\mathrm{J}$ Am Soc Echocardiogr. Mar. 27(3):230-8; 2014.

\begin{tabular}{|c|l|}
\hline \multicolumn{2}{|c|}{ Access this Article in Online } \\
\hline Q & Website: \\
& www.ijcrims.com \\
& Subject: \\
Quick Response Code & \\
\hline
\end{tabular}

How to cite this article: Mohamed Mahmoud, Mohamed Salah A. Elsalam, Hatem A. elrahman and Tarek A.M. Khalifa. (2017). Speckle tracking versus tissue Doppler assessment of Right ventricular function in inferior wall myocardial infarction and angiographic correlation to proximal right coronary artery stenosis. Int. J. Curr. Res. Med. Sci. 3(5): 47-60. DOI: http://dx.doi.org/10.22192/ijcrms.2017.03.05.009 